Article

\title{
Crisis, Urban Fabrics, and the Public Interest: The Israeli Experience
}

\author{
Hadas Shadar ${ }^{1,2}$ \\ ${ }^{1}$ Department of Architecture, NB Haifa School of Design, Israel; E-Mail: hadass2@013.net \\ 2 Faculty of Architecture, Technion-Israel Institute of Technology, Israel
}

Submitted: 15 April 2021 | Accepted: 8 June 2021 | Published: 17 November 2021

\begin{abstract}
The relation between urbanization and pandemics is not new. In fact, the "reformative" urban plans of the late 19th and early 20th centuries sought the addition of green patches, reliable running water systems, good sanitation, and sunlight to fend off the common ailments of the industrial city. No wonder then that these urban planning elements are also compatible with the Covid-19 era, as ample green and low-density areas are supposed to ensure or at least support quality of life and good health, even amid the health crisis we face today. This article examines whether additional elements tie together urban fabrics and coping with crises, particularly pandemics. To answer this question, I examine national urban planning in the state of Israel from the mid-20th century onwards. Urban planning in Israel has implemented theories and precedents from Europe and America; however, Israeli planners have also included nationalist-ideological contents in their work, so that the state and its interests have dictated their planning. The article concludes that the state interest of producing a cohesive society has created Israeli urban fabrics with community values and proximity to green areas, which are better suited for individual coping with crises involving the denial of personal freedom, whether due to a pandemic or any other reason. Accordingly, it proposes viewing these elements as suggestive of the need for significant involvement by public representatives in future urban renewal efforts.
\end{abstract}

\section{Keywords}

communality; Covid-19; ideological planning; state planning; urban fabrics

\section{Issue}

This article is part of the issue "Towards Digital Urban Regeneration: Embedding Digital Technologies Into Urban Renewal Processes and Development" edited by Dalit Shach-Pinsly (Technion-Israel Institute of Technology, Israel).

(C) 2021 by the author; licensee Cogitatio (Lisbon, Portugal). This article is licensed under a Creative Commons Attribution 4.0 International License (CC BY).

\section{Cities and Pandemics: Nothing New Under the Sun?}

Following the Covid-19 outbreak, the past year has seen multiple articles that have associated contagion through human interaction and density (e.g., Kaushal \& Mahajan, 2021), particularly urban density (Liu, 2020). It was found that in metropolises, contagion rates were higher due to the density of residential spaces (Bereitschaft \& Scheller, 2020; Carpentieri et al., 2020). Trains and airplanes travelling between metropolises helped spread the virus (Gupta et al., 2021). Within the cities, the highest contagion rates were in poorer neighborhoods (Ito \& Pongeluppe, 2020), among other things due to the large number of occupants in each housing unit (Mendes, 2020; Wasdani \& Prasad, 2020). The main problem, however, was found with regard to the urban experience, which is based on interactions with strangers outside one's immediate social network, in random encounters in commercial areas, cultural venues, and public transportation. Indeed, the frequent human friction is a leading cause of contagion (Iranmanesh \& Alpar Atun, 2021).

Other recent studies have pointed to the human need for the comfort provided by green spaces in times of lockdown (Carpentieri et al., 2020; Ugolini et al., 2020; Zhu \& Xu, 2021), particularly in cities (Tendais \& Ribeiro, 2020). Some argue that in the city, green areas should be considered critical infrastructures (Gugerell \& Netsch, 2020).

The virus is new and so are the articles-but what about the conclusions? An examination of urban design theories that developed in the aftermath of the Industrial Revolution shows that there is nothing new 
under the sun. Indeed, the desire to provide better quality of life to its inhabitants, and particularly avoid the epidemics that spread in its poor conditions, pushed planners to come up with solutions. Indeed, some of the most influential urban theories of the turn of the 20th century sought to "reform" the faults of the industrial city. They aimed at giving back to the city what it had lost due to excessive urbanization: order, peace, clean air, daily presence of nature, and healthy living conditions such as natural light, ventilation, and hygiene (garbage disposal and sewage systems; Jabareen \& Eizenberg, 2021).

For example, Howard's (1898/1960) garden city was based on zoning designed to prevent the industrial zones from polluting the air, and especially on low-density housing around parks to prevent illness and renew the inhabitants' direct contact with nature. Similarly, Tony Garnier's cité industrielle was based on zoning and green urban housing blocks with low-concentration and low-level housing that was not to exceed tree height (Wiebenson \& Garnier, 1969). La Corbusier's cité radieuse (1929/1947, 1933/1967) was based on zoning and tall buildings set within an infinite garden, to provide the inhabitants with sunlight and landscape despite high density.

In the same context of public health and contact with nature, we can also mention urban fabrics. One of them is landscape architect Leberecht Migge's Green Manifesto, developed in 1919, shortly after the Great War. Migge called to base German housing on single-family homes with auxiliary farms to provide for their domestic consumption (Haney, 2007). Another fabric worthy of mention is the zeilenbau (row houses, slab buildings) approach developed by Walter Gropius to prevent the building of dense and dark urban blocks and ensure the tenants' "solar rights" (Giedion, 1954).

Note, however, that these green solutions did not settle for "reforming the industrial city" by providing its inhabitants with improved housing conditions. Some of them threw the baby out with the proverbial bathwater by doing all they could to rid the city of its urbanity, seen as the mother of all sins. Thus, in physical terms, some of these theoretical solutions did not include the basic building blocks of the pre-industrial city, such as streets, boulevards, urban blocks, and welldefined squares (Krier \& Economakis, 1992). Humanly speaking, the fabrics planned were stretched too thin to enable meaningful encounters. Functionally, the mixture of urban uses was cancelled. For all those reasons put together, these solutions failed to provide the conditions for the urban pulse: they provided inappropriate infrastructure for urban diversity and spontaneous interactions between the inhabitants throughout the day and night.

Accordingly, it appears that the years 2020-2021 tell us little that is new. The high urban density and intense human interactions typical of good urbanity also promote contagion-the Covid-19 outbreak in low urban density makes it easier to maintain the social distance imposed in the early months of the crisis. It therefore appears that anti-urban, thinly populated, and thickly green spaces are indeed optimal for fending off pandemics.

The present article explores whether this is indeed the case, or whether there are additional deep undercurrents that associate the struggle against pandemics with anti-urban theoretical fabrics and concrete precedents. To answer the research question, the following will examine the Israeli experience in urban design, designated mostly for the country's Jewish citizens and executed by the Ministry of Housing (in different periods, also referred to as Ministry of Construction and Housing). The article will focus on the urban fabric: the relationship between the constructed and open areas, the configuration and interrelations of the buildings, and the road system.

Israel was selected as a case study for three main reasons. First, its state architects were informed by European and American theories that contained antiurban elements. This was because they studied in Europe or from architects educated in Europe, making Israel a case study of Western theories and precedents (Shadar, 2014). Second, Israeli planning applied these to the construction of new towns and neighborhoods on lands that were empty or considered empty. Accordingly, Israeli town planning often articulated a complete planning concept that did not have to take certain constraints into consideration (Shadar, 2014). Finally, Israeli planning included certain elements in addition to the European ones. Naturally-as may be expected in the implementation of precedents or theories in a different culture and location-the copy turned out somewhat different from the original. In particular, it was charged with local ideas. The article examines these ideas to identify undercurrents that connect the anti-urban fabrics and the perceived need to cope with emergencies.

The specific examples in this article are drawn from studies of the development of state planning throughout Israel's history (Shadar, 2010, 2011, 2013a; Shadar \& Oxman, 2003). These suggest that Israeli state planning may be divided into distinct periods, not necessarily differentiated by geographic or demographic characteristics. Therefore, examples faithfully representing the planning periods have been selected.

\section{The Israeli Experience and International Precedents}

Upon the establishment of the state of Israel in 1948, the State Planning Department was created, headed by Arieh Sharon (Sharon, 1976). The department's plan for the decentralization of the Jewish population and for planning new settlements was published three years later. The 1951 plan offered a uniform pattern for the new towns and neighborhoods. Their scheme was radial, with the urban center at the geographical center and the residential neighborhoods around it. Both the center and the neighborhoods were separated by green areas, with 
only a single road dedicated to connecting the neighborhoods to the urban center, and the neighborhoods to each other (Sharon, 1951). The explanation provided by the planners was based directly on the bitter experience of the European industrial city: "The old cities in Europe as well as Israel," they wrote, "are built as a monotonous sequence of houses, streets and residential neighborhoods that stretch to infinity, making the inhabitants' lives unbearable" (Sharon, 1951, p. 8). The construction in the disjointed neighborhood followed the same logic: the houses were small, with few housing units each, and bathed in large green areas within each neighborhood; some also included an auxiliary farm. A neighborhood center was planned for each (Sharon, 1951; Figures 1 and 2).

What were the direct precedents for the Israeli planning? As suggested, local planning learned from the theories and precedents that rejected the model of the European industrial city-despite the fact that neither Israel nor pre-1948 Mandate or Ottoman Palestine contained any such cities. The direct precedent for the Israeli planning was the new towns planned in Britain during WWII and built thereafter (Shadar \& Oxman, 2003), and the indirect precedents were Howard's garden city theory and American town planner Clarence Perry's neighborhood unit. Both the neighborhood unit and the garden city were direct precedents of the new British towns and indirect precedents of the Israeli planning.

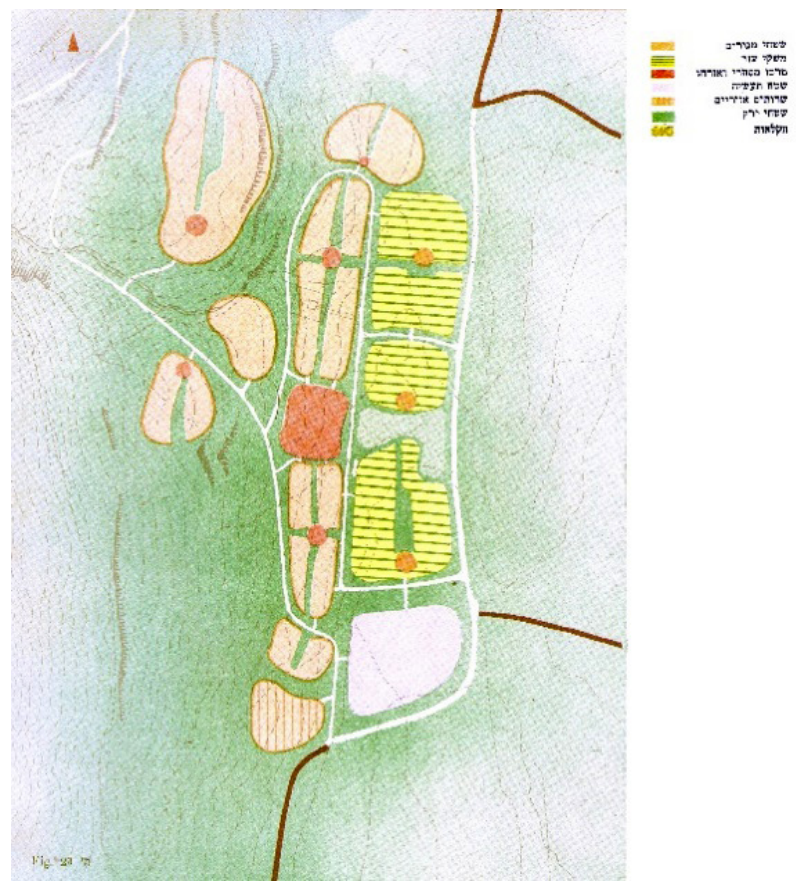

Figure 1. The new town of Kiryat Shmona: Disconnected neighborhoods. On the right and in yellow, auxiliary farm neighborhoods. Notes: From top to bottom, it is written "residential areas," "auxiliary farms," "commercial center," "industrial zone," "regional services," "green spaces," and "agriculture." Source: Sharon (1951, p. 37).
Perry (1929/1974) considered the neighborhood a community unit revolving around central community institutes, with reasonable walking distances of some $400 \mathrm{~m}$ from the neighborhood center to the most distant house. British town planning, which combined the two sources of influence, and the Israeli planning that studied it, took a step further, connecting the thinly populated residential neighborhoods of the garden city to the community neighborhood unit to the point of actually imposing communality on the residents: It was difficult to get out of a neighborhood separated from others by green belts (Abercrombie, 1945; Merlin, 1971). Similar to the new British towns, the Israeli neighborhoods featured an oval road system, regardless of topography, that lengthened the roads and infrastructures, and was in fact wasteful in terms of water, sewage, drainage, electricity, road, and sidewalk infrastructures.

In the 1960s, that concept of the neighborhood as a disconnected unit was not revised, but due to the waste involved in the oval road system, it was modified to become straighter and the building positions were also changed (Cecik, 1968). With the improvement in construction capabilities, the open plan model was adopted, recalled from the heritage of Le Corbusier, as was

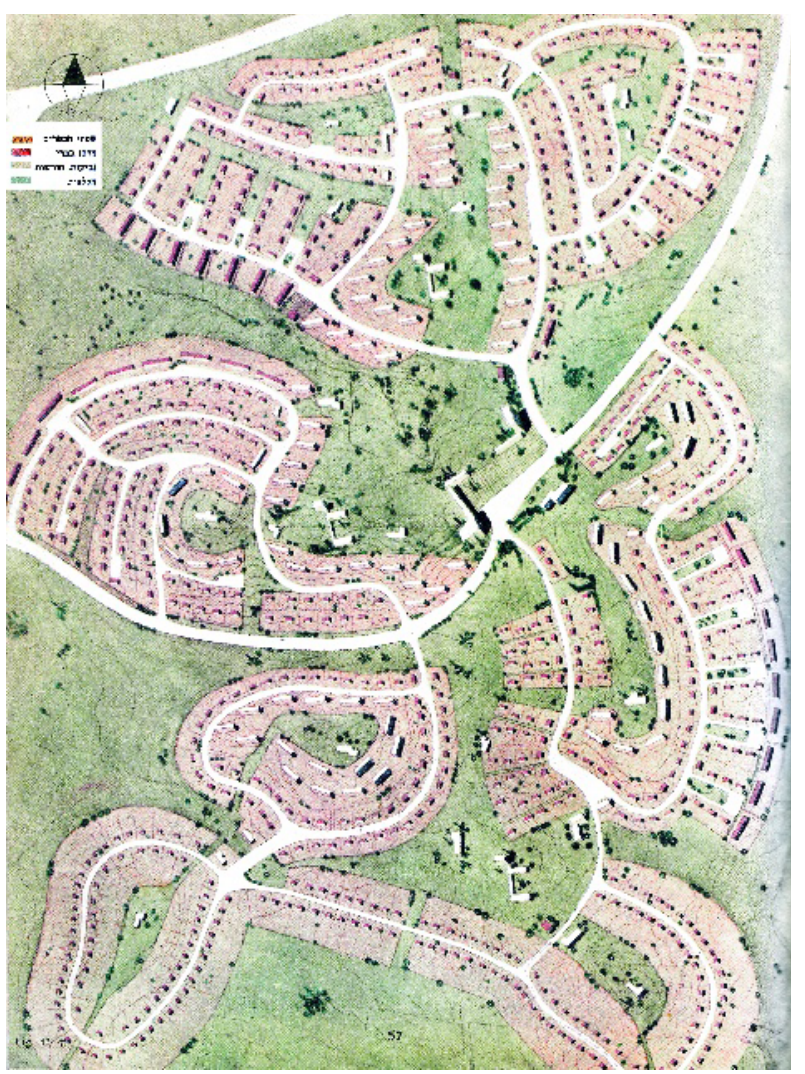

Figure 2. The neighborhood unit plan in Ashkelon's southern neighborhoods. Notes: From top to bottom, it is written "village areas," "rural center," "plantings, groves," and "agriculture." Note that the legend refers to the urban neighborhood as if it were a village. Source: Sharon (1951, p. 57). 
Gropius' zeilenbau. Both were averse to the (industrial) city and sought to turn their back on it, by positioning the buildings in a way that did not create urban spaces such as streets or squares and keeping the open space dominant. Following the same logic, the buildings were turned to face the endless communal green areas, as if expressing the idea that it is there that the coveted quality of life lies (Figures 3 and 4).

In the 1970s, Israeli planning gave up on the extensive green belts between the neighborhoods, as experience had shown that in Middle Eastern countries the green areas on the drawing boards turned yellow and fallow in real life. Instead, the neighborhoods were separated by broad motorways crossing the city, in keeping with the Western trend of privileging the comfort of motorists over that of pedestrians (Jacobs, 1961). The condominiums in the neighborhoods became taller and denser. Vehicle traffic reached only the edge of the plot, into the parking bays, so that the heart of the neighborhood was inaccessible to motorized traf- fic. Within the neighborhood, a communal green courtyard was planned, towards which pedestrian routes were channeled. This is where the neighborhood public buildings and domestic consumption stores were located. Both the courtyard and the public institutes and small shops were known to the neighborhood residents only, who overlooked them from their rooms, from their terraces, and in many cases also from their house entrances. The community-neighborhood courtyard was surrounded by residential buildings usually no more than 4-6 stories high, to prevent a situation where the neighbors were too many and therefore too anonymous (Harlap, 1973, 1977; Figures 5 and 6).

Here too, the precedents were European and American. Having the courtyards surrounded by residential buildings was typical of planned European construction in the late 1960s and 1970s (Golany, 1976). Separating pedestrian from motorized traffic was the order of the day in British town planning, from which the Israeli planners learned (Ritter, 1964). Add to that the

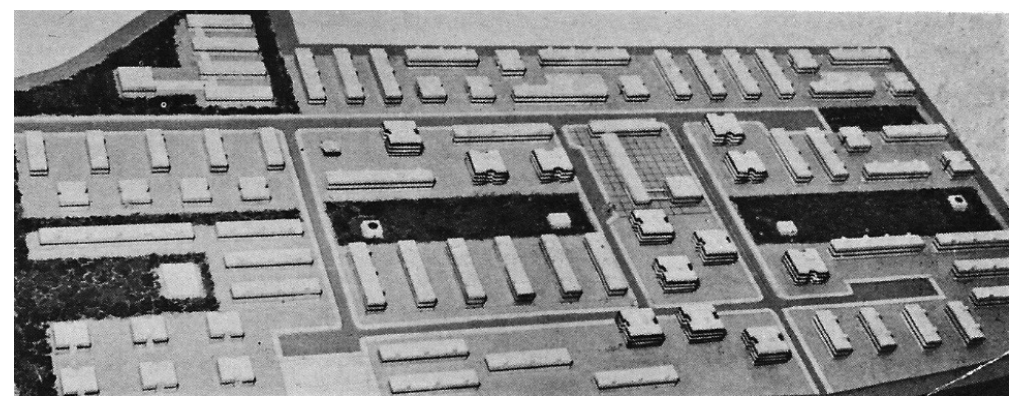

Figure 3. Model of neighborhood construction in Netanya, combining zeilenbau and the open plan. Source: Ministry of Housing (1964).

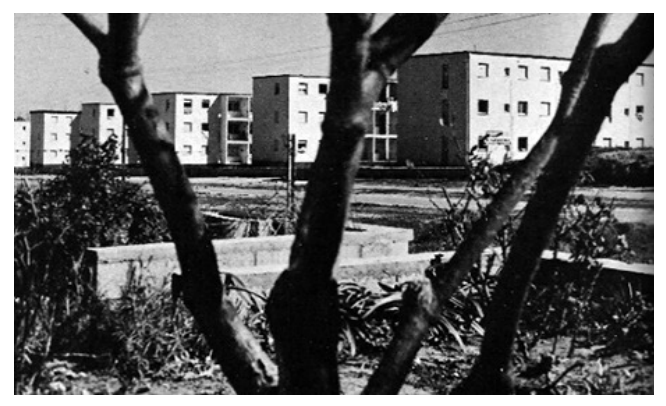

Figure 4. Zeilenbau condominiums in Netanya. Source: Ministry of Housing (1964).

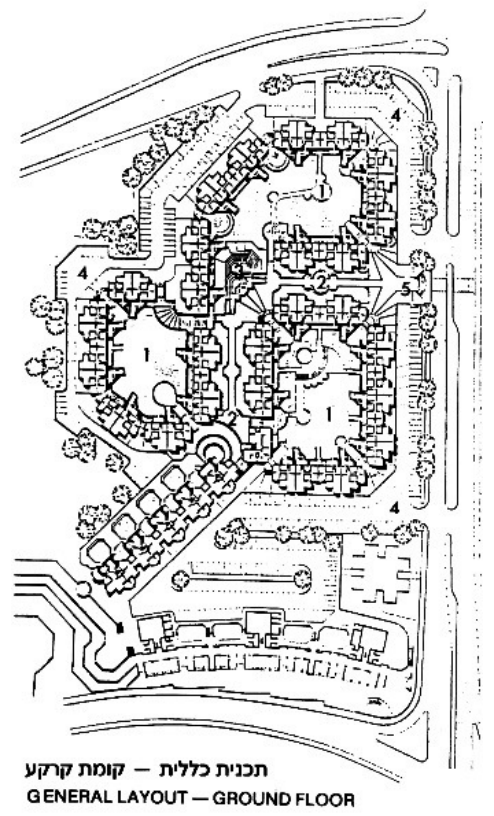

Figure 5. Complex planned by Salo Harshman in Gilo, East Jerusalem. General layout: Ground floor. Source: Harlap (1988, p. 113).

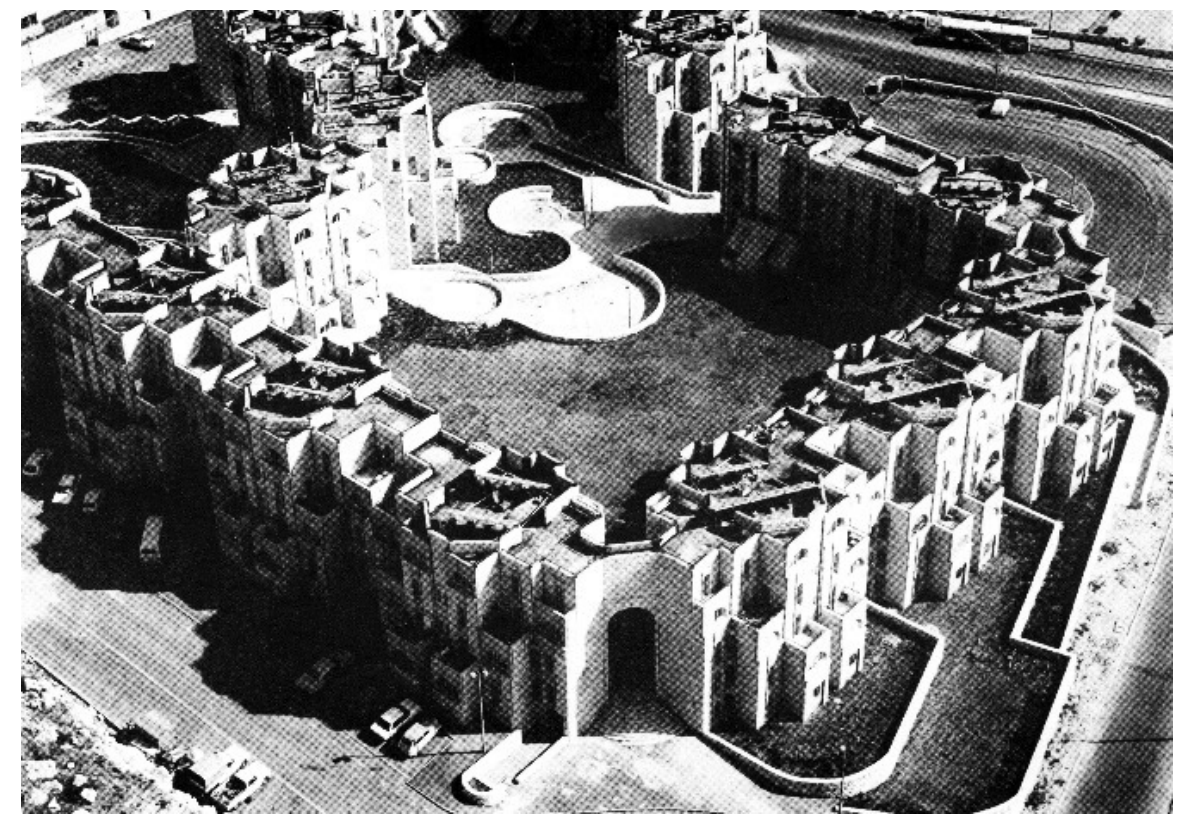

Figure 6. Overview of the complex planned by Salo Harshman in Gilo, East Jerusalem. This design means that the tenants see each other and the inner green area from their apartment windows. Source: Harlap (1988, p. 114). 
precedent of the New Jersey suburb of Radburn (1929), planned by Clarence Stein and Henri Wright, which was based on having the houses face the green areas, where intra-neighborhood traffic was strictly pedestrian (Stein, 1949).

In the 1980s, the seed was sown for a sea change in state planning in Israel, which sprouted in the 1990s. It relied on various lessons learned from the failures of the previous models (Paldi et al., 1989). And as usual, the new model adopted was inspired by the Western town planning. The model this time was "the return to the traditional city," meaning the European pre-industrial city, with its streets, boulevards, squares, and urban blocks (Krier, 1984; Krier \& Economakis, 1992). In Israel, most of whose artificial towns were built out of an anti-urban agenda, there were few urban models to learn from, or to wax nostalgic about (Knox, 2005). Therefore, the idea was to learn from Scottish town planner Patrick Geddes, whose plans for Tel Aviv were drawn from 1927-1929, under the British Mandate rule. Geddes' plan provided a judicious basis for Tel Aviv's development based on an open, hierarchic network of streets. The urban pulse of the country's business capital was the reason why the Geddes Plan became the model, rather than other historical precedents such as Sitte's (1889/1945) theory of city building according to artistic fundamentals, or Taut's (1919) crown city theory.

Indeed, within a few years, in an atmosphere of intensive planning motivated by the massive immigration of Jews from the former Soviet Union, houses were planned on the edge of mixed-traffic (pedestrian and motorized) streets, which were multi-purposed (housing and commerce), and urban blocks were outlined (Safdie, 1991; Shinar, 1990; Figures 7 and 8). In 2000, urbanity represented Israel in the Venice Biennale. The curator, architect Hillel Schocken (2000), defined urbanity as "intimate

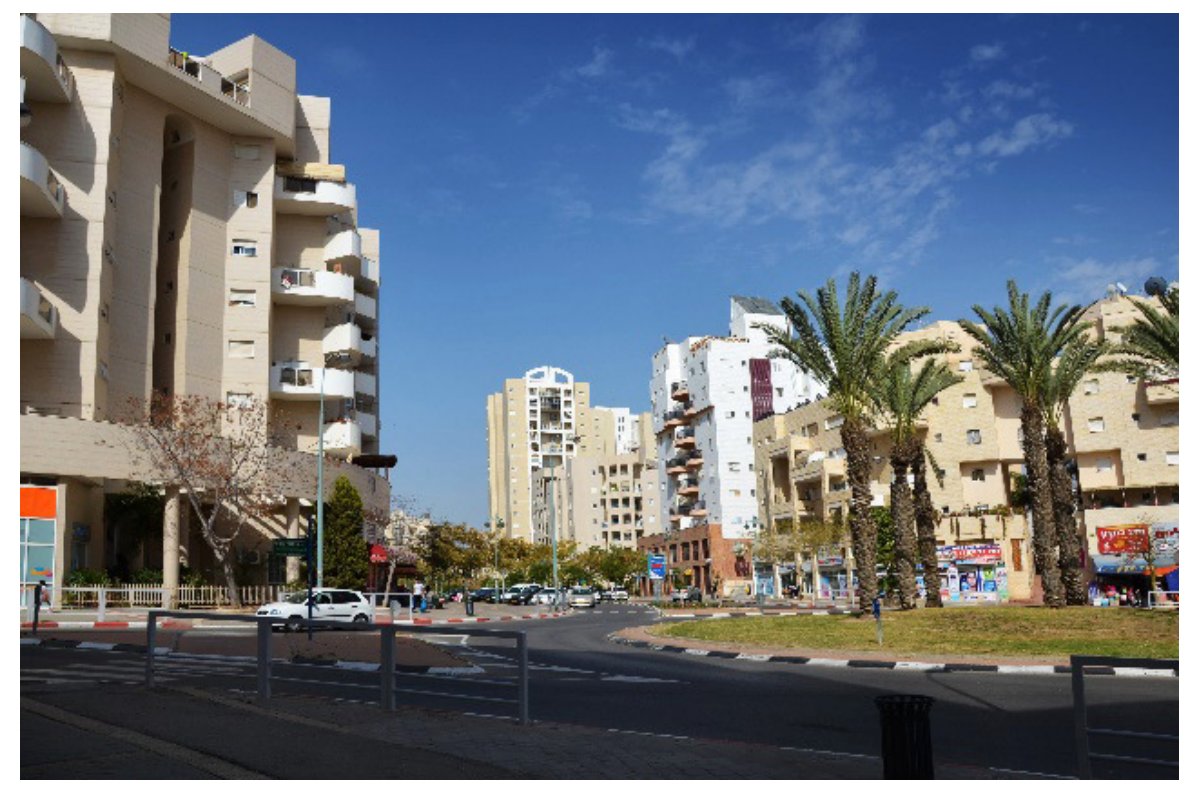

Figure 7. Mixed-use main axis in Neve Zeev Neighborhood, Beersheba, by AMAB Architects (1990s). Each building was planned by a different architect.

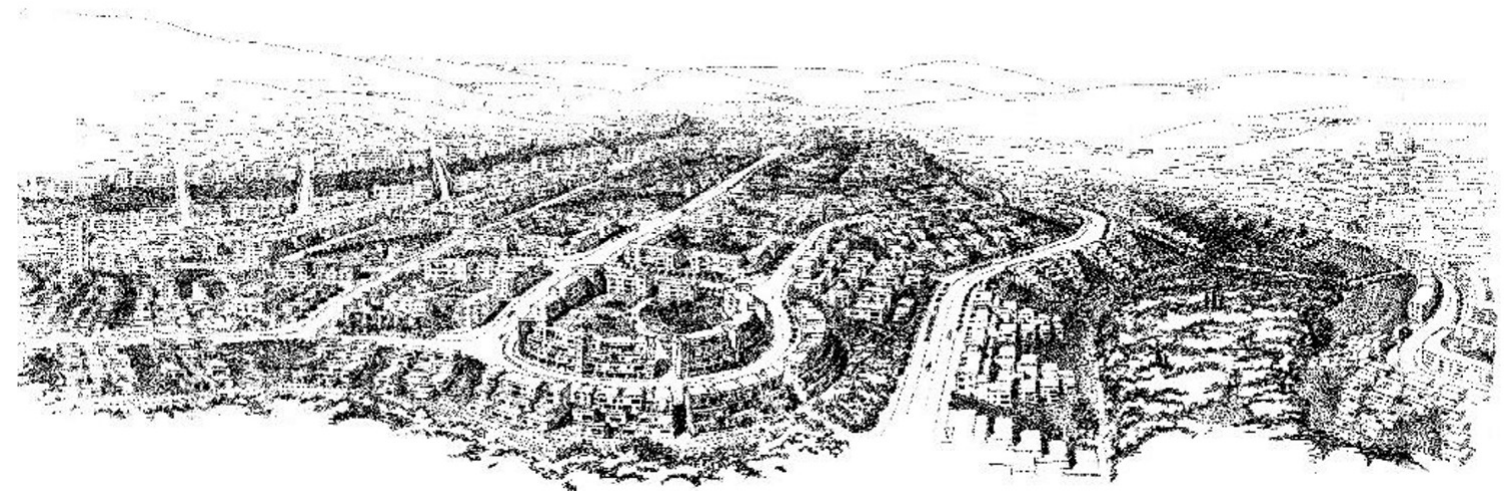

Figure 8. Kaiser Neighborhood in Modi'in, 1992-2000. The city is designed with urban blocks or standalone buildings facing the streets, as opposed to the past, when the buildings would face internal green areas and the streets would be planned particularly for motorized traffic. Source: D. Kaiser, M. Kaiser, and I. Leckner-Architects \& Town Planning (personal communication, 2012). 
anonymity." In other words, the anti-urban approaches were dead, replaced by revived approaches that celebrated urbanity and constructed it based on the finest Western urban insights.

\section{The Ideological Undercurrents Feeding the Adoption of Urban Precedents}

Was Israeli planning informed only by copying and learning from Western precedents and theories? The answer, as suggested in the introduction, is negative. Precedents are adopted out of prosaic reasons: They are learned in the local schools of architecture (indeed, they have been), or brought with Jewish architects immigrating from Europe or America to Israel. But this is not enough. In order for an architectural precedent to become established in a different country and culture over the long term, it must also match the overt and covert ideology of that country and culture (Shadar \& Oxman, 2003). This is the story of Israeli state planning.

In the 1950s, during the first years of statehood, the green planning articulated primarily the passion for the land (Cohen, 1970) typical of recent immigrants who seek to establish themselves in the new territory. The added value of those disjointed neighborhoods was communality. In this case as well, we could say that this is historically international value, since the modernist city was overcrowded and alienated, certainly compared to the villages from which people had moved to the city in the years of the Industrial Revolution. Nevertheless, the need for community was very much local and critically so in Jewish-Israeli society of the 1950s, which was made up of a huge diversity of immigrants from all over the world, whose arrival doubled the country's population within three years.

In the 1960s, the years of the open plan or zeilenbau, green belts still dominated the plans and landscape, but were more practical in character. Apartments were bigger, allowing greater scope for family life, albeit not yet at a sufficient level. Accordingly, the green areas between the row houses were supposed to provide an extension of individual daily life, and particularly of the communities. Thus, the values of attachment to the land and community were still powerful.

In the 1970s, Jewish-Israeli society underwent a significant transformation. As a result of two wars, in 1967 and 1973, and the growing dominance of the younger generation, particularly second-generation Asian and African immigrants, the heterogeneity of Israeli society, that was successfully subdued over the previous decade (Eisenstadt, 1989), gained public visibility. Ethnic tensions rose to a fever pitch until the ruling party was replaced in the 1977 elections, for the first time in 29 years. Nevertheless, the housing fabrics planned at the time-condominiums with rigidly defined inner courtyards, to which the rooms and pedestrian traffic routes were directed (Mertens \& Golani, 1973)-still enforced the "community." The housing blocks forced the gaze to turn into the inner courtyard, and from balcony to balcony, imposing an inner convergence of the tenant "community," involving acquaintance and daily contact among the neighbors-even if that was not desirable to them. It is no coincidence that the car, which enabled moving out of the neighborhood, remained in parking bays in the rear. Ostensibly, this provided extra safety within the neighborhood. In fact, however, it was designed to deny the individual freedom to leave the neighborhood. This can be seen as a rearguard attempt by the planners to fend off the now externalized social heterogeneity that frightened them by forcing Israeli society into a melting pot that has long since melted away (Shadar, 2013b). In terms of values, the planners sought to promote the sense of community. The value of attachment to the land was largely abandoned. It was only partly articulated in the green courtyards at the heart of the neighborhood. Conversely, community became a dominant value, precisely because it represented a fantasy more than a reality.

The social transformation mentioned above-the externalization of Israel's social heterogeneity-sowed the seeds of the "return to the traditional city" in the 1980s and boosted the growth of the pro-urban fabrics in the 2000s. The establishment architects, who failed in their rearguard action to unify Israeli society, adopted the principles of urbanity, and managed to imbue them with ideological significance. This time, it was about the individual, democratic freedom of moving across the city and selecting the public institutes and commercial outlets out of the huge urban supply spread along continuous, mixed-traffic streets that are open to all users. Demetri Porphyrios (1992, p. 10) argued in the Introduction to Leon Krier's book that "the traditional city... underlines the individual and the contingent" - the Israeli planners of his day would surely have agreed.

The Ministry of Construction and Housing that employed the state planners followed the same agenda. The personal freedom insight also produced organizational changes. Whereas in the past, a few construction companies dominated all the work initiated by the ministry, and the architects planned the housing fabrics-from the community courtyards to the building details-now planning became privatized as well. Various contractors built in the neighborhood and various architects planned it: The neighborhood planners were different from the neighborhood segment planners, who in turn were different from the building architects (Shadar, 2014).

The process gained momentum. With the slowing down of the 1990s immigration from the former Soviet Union, the ministry continuously reduced its direct construction projects - that is, reduced its own power, as opposed to the power of the individual. The ministry focused on its administrative and guiding role. Its most significant contribution in the 2000 s was issuing construction manuals that outlined the conditions for encouraging urbanity: from street planning manuals 
through guidelines on planning urban gardens and green passages to manuals for condominium planning (Frisher, 2009; Lerman, 2008; Parhi-Tzafrir Architects \& Geoda, 2011; Shapira \& Han, 2008; Trop \& Sarig, 2012).

The reduced role of the Ministry of Construction and Housing as an active builder was accompanied by the expanded role of the urbanity discourse in academic and public circles. This change in public opinion is indicated, for example, by multiple Facebook groups dedicated to urbanity and Henri Lefebvre's (1968) "right to the city" (Figure 9; e.g., the Israeli Facebook groups Renewed Urbanity in Israel, Forum for Urban Renewal, and Urban Design Research Group). Competitions for promoting urbanity are held frequently, as are conferences on the same subject (see, e.g., Israeli Urban Forum and its conferences, such as the Acre Urbanity Conference; The Israeli Urbanism Forum, n.d.). An urban design lab and urban clinic were established at the Tel Aviv University (2015) and the Hebrew University of Jerusalem (n.d.), respectively. The frequent destruction of old housing blocks in favor of new and much denser ones is euphemized as "urban renewal." The ideology mobilized to justify this celebrates urban density and the need to maintain the green areas outside the cities. Although the motivation is entrepreneurial, and the funding for the destruction and reconstruction is private, the Ministry of Construction and Housing supports the growing trend, which largely erases the old neigh- borhoods built by the same ministry in the 1950s and $60 \mathrm{~s}$, as described above (Ministry of Construction and Housing, n.d.).

How can this transformation be summarized? Growing individualism, together with the demand for individual freedom at the expense of the idealized communality in the early years of statehood, and its imposed version later encouraged the transformation in housing fabrics into urban ones. At the same time, they encouraged an establishment, academic and public discourse that privileged individual interests, private enterprise, and dense and vibrant urbanity with multiple uses and building types and celebrated that urbanity as the exclusive ideal. As a by-product of this ideological development, the state-practically the only entrepreneur, planner, and contractor during its first thirty-forty yearsgradually reduced its powers and deliberately strengthened the free market in the construction area, as in others (Bareli et al., 2005).

Therein lay the rub, however. Socially, neoliberalism, which relied on the value of personal freedom, proved detrimental to the various forms of institutional communalism. The cut back on social benefits, privatized health, and education no longer took responsibility for housing young couples and the needy, and left the individual citizens to their own devices, supported by only a weak safety net. Needless to say, the neighborhood structure no longer expressed community

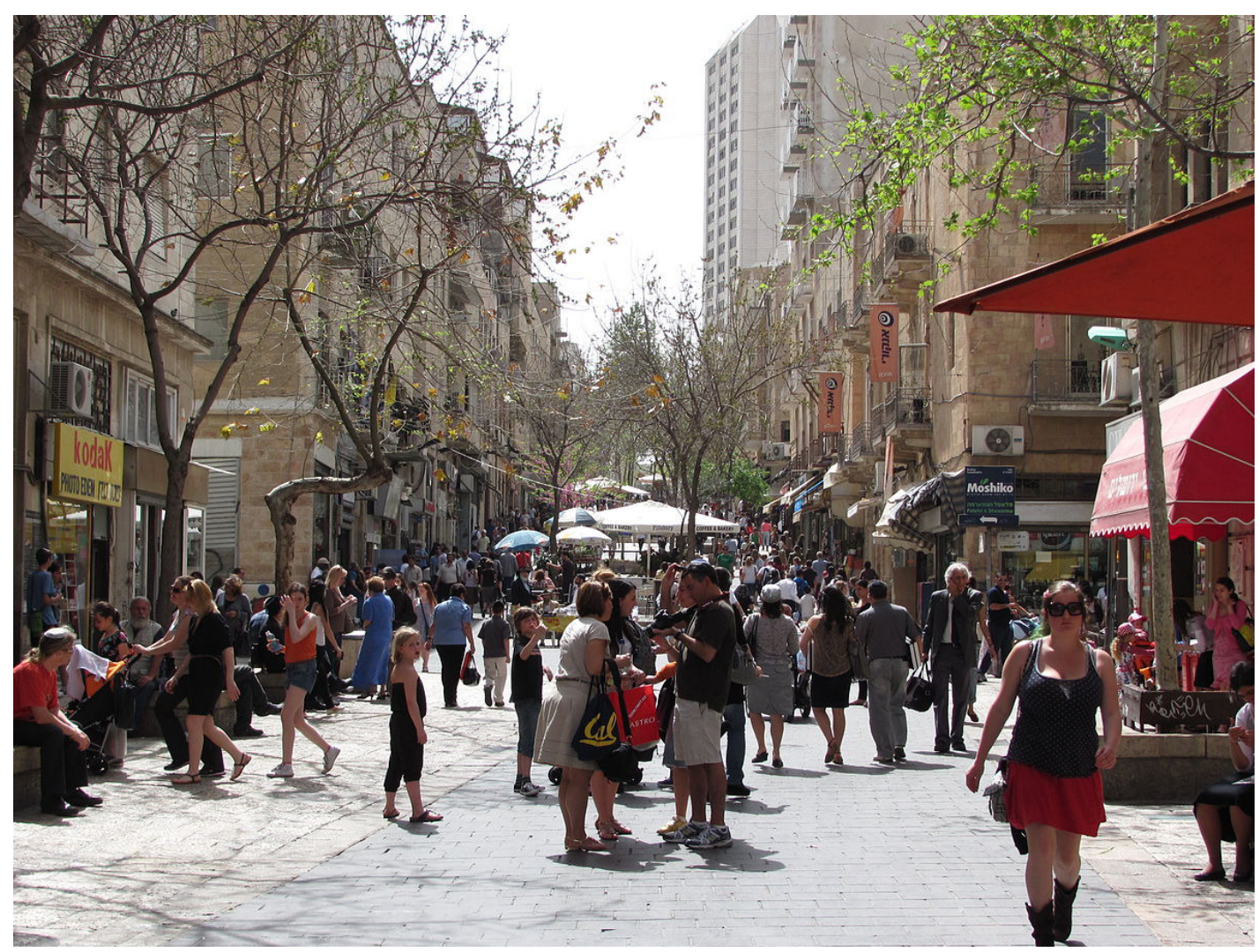

Figure 9. Ben Yehuda Street Pedestrian Mall, Jerusalem, serving as the theme photo of the Facebook group Renewing Urbanity in Israel. Source: Yoninah (2011). 
values. Moreover, whereas at the beginning of the privatization process, the state did give way to small-scale bottom-up civilian initiatives that diversified the desirable public space, things changed: Entire neighborhood public spaces were abandoned to the interests of huge private entrepreneurs who built or "renewed" them. These spaces lacked the diversity sought by state planners back in the 1990s, and are little more than gigantic "housing containers," with little in the way of added community value (Figure 10).

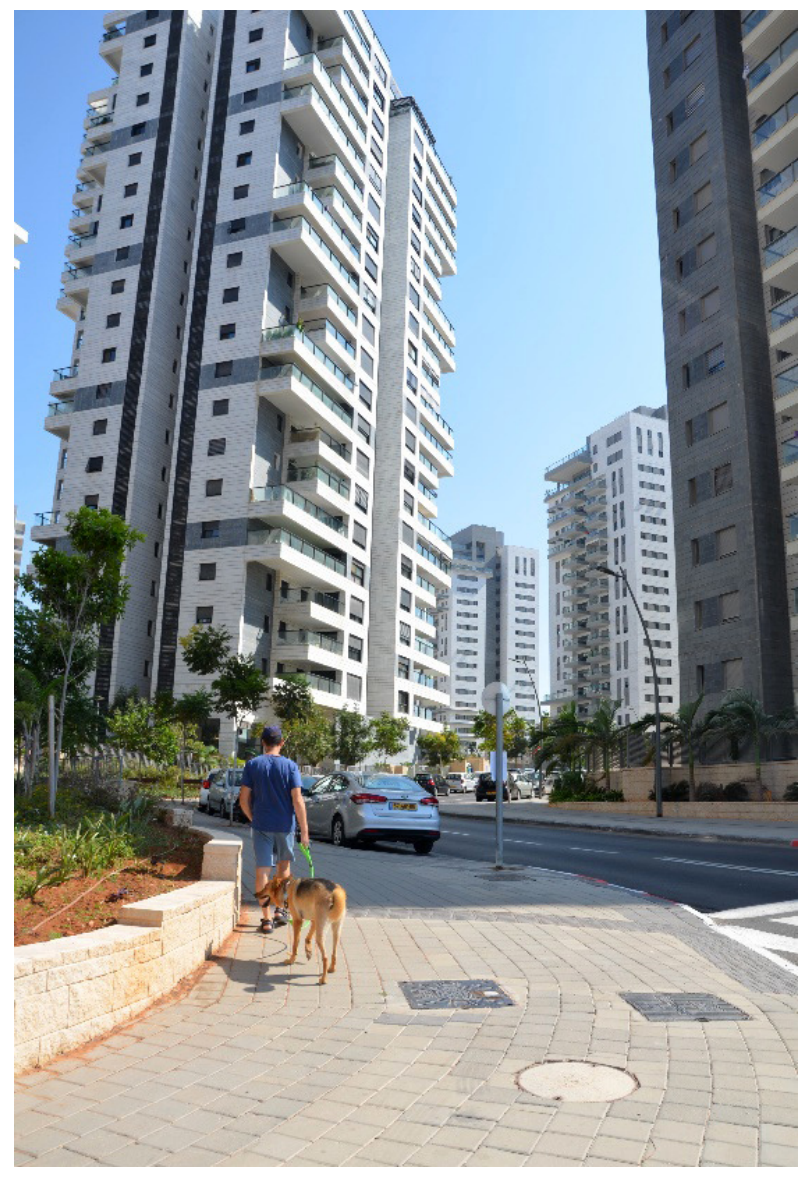

Figure 10. Public spaces of a new neighborhood in Rosh HaAyin. An example for a street without interest and uses other than housing.

\section{Conclusion: "Us” Plans}

As mentioned in the beginning, the housing fabrics developed around the turn of the 20th century were motivated by the desire to minimize the impact of the epidemic outbreaks typical of the European industrial city. These fabrics, most of which were rich in green areas, some of which were even anti-urban, are gaining in popularity these days following the Covid-19 pandemic, given the well-documented fact that the dense urban construction and free and random encounters offered by any vibrant city serve to spread the virus. I argue, however, that this is only part of the story, as the Israeli experience clearly shows that additional "players" make those fab- rics more suitable for dealing with pandemics and with crises in general. These players are the state and major public entities, and the community ideology embedded in their planning.

Dekel's (2021) book is an adapted diary of his life under siege in the Chinese city where the Covid-19 pandemic broke out. It emphasizes two issues relevant to our purposes. The first is the need for a warm and neighborly community: "You realize that now, wherever we live, it would be within a warm community, and not in a lonely building without neighbors" (p. 86). Indeed, a recent study highlighted the positive relationship between a cohesive community and successful coping with Covid-19 (Baqer et al., 2021). The second issue is the need for immediate contact with the community by looking out the window: "What helps us keep sane in a nearly two-month quarantine is the immediate contact with the outside world. One of the ways to remain up to speed is simply look out the window.... do it a lot" (Dekel, 2021, p. 133).

The history of state planning in Israel indicates that the value of community is associated with sparsely constructed and anti-urban fabrics. Although this value was part of the historical dealing with the massive and alienated city - as in Perry's neighborhood unit (1929/1974) refining the architectural expression to the point of imposing community could not have taken place without the state's decisive power. The architects' collaboration with the state produced neighborhoods with little in the way of individual freedom and urbanity. This is particularly true of the inner courtyard-based neighborhoods of the 1970s. In these neighborhoods, state architectures sought to produce spaces of the community, instead of that "intimate anonymity" representative of the urban experience, according to Schocken (2000).

With regard specifically to architecture, when we see the neighbors' balconies all facing the same green garden (Figures 3 and 4 , and particularly 5 and 6 ), the sense of togetherness is empowered, and tenants can draw comfort from a green, live landscape. With regard specifically to the Covid-19 crisis, when states lock people in and deny them the freedom to wander and choose, which is essential to good urbanity (Freudendal-Pedersen \& Kesselring, 2020; Zecca et al., 2020), and particularly when civilians cooperate out of internal identification, fabrics that from the very beginning have relied on the value of the community rather than on urban experience, freedom of choice, and individual mobility are preferable. These spaces are perfect for crises because whatever form the crisis takes, be it pandemic, war, or natural disaster, the individuals with their self-centered needs and daily wars make way for the power of the community and mutual responsibility.

Recent studies about coping with Covid-19 indicate that this was the finest hour of states and international organizations (Anttiroiko, 2021). Municipalities were able to act within the boundaries charted by the government, and the effectiveness of large public 
movements was demonstrated by their ability to influence the government (Mendes, 2020). The management of national transportation lines, the delivery of knowledge, medical examinations, and healthcare (Lak et al., 2020), as well as the decision to defer mortgage or rental payments to prevent the evacuation of the unemployed (Mendes, 2020) were government decisions taken and implemented together with additional civic and international bodies (Ito \& Pongeluppe, 2020). In other words, coping with large-scale crises requires significant state actions. The long arm of the private market, which dominates our routine, is not long enough.

To return to the urban fabrics, it is no coincidence that in Israel it was the state that planned the community fabrics, nor is it a coincident that these fabrics, where the community is seen through the window, are more suitable for handling crises. The public interest and ideology that favor togetherness have produced these fabrics. This is also the answer to the research question regarding the additional, ideological element in urban construction suitable for coping with crises: (1) Community fabrics are better suited for coping with crises, and (2) community fabrics are planned by planners working for the public or its representatives.

A word about the future. The values central to this article-attachment to the land and community-have not disappeared, nor are they expected to. They are part of our human needs. Community gardening, sustainable planning, and spatially active social networks are no more than the contemporary translation of those needs, which are met by the free market and civil society in isolated sites in physical and virtual space in the neoliberal age. In times of emergency lockdown, when vibrant urban spaces have been locked down by command, and with the restriction of mobility to neighborhood spaces, these were found lacking. It was revealed that occasional or virtual encounters cannot replace a sound community planning basis. That, marginalized by free choice that justifies "good urbanity" are large populations whose reduced mobility does not enable them to enjoy all that the city has to offer (Sepe, 2021), and that the older and poorer are sicker and otherwise disproportionately weakened in times of lockdown and crisis (Ito \& Pongeluppe, 2020; Mendes, 2020). Worst of all, the new and supposedly "urban" public spaces abandoned to entrepreneurial interest were exposed in their inappropriateness. Therefore, there is no choice but to have the attentive government or significant public entities representative of community needs reassume the role of designing public spaces. This need not do so as omniscient and omnipotent entities, but as another player in the arena. A player that can take responsibility for the weak and embody the value of community in space.

\section{Acknowledgments}

I thank architect Kobi Haina for helping me hone the message of this article.

\section{Conflict of Interests}

The author declares no conflict of interests.

\section{References}

Abercrombie, P. (1945). Greater London plan. His Majesty's Stationary Office.

Anttiroiko, A. V. (2021). Successful government responses to the pandemic: Contextualizing national and urban responses to the Covid-19 outbreak in East and West. International Journal of E-Planning Research (IJEPR), 10(2), 1-17.

Baqer, M. H., Al-Mudhaffer, A. F., \& Kadhum, G. I. (2021). An analysis on capacities of old fabric in social resilience of city against Covid-19 epidemic: A case study of old fabric of Najaf Ashraf City. Journal of Engineering Science and Technology, 16(2), 1814-1824.

Bareli, A., Gutwein, D., \& Friling, T. (2005). Cheker hachevra vehacalcala belsrael: Hitbonenut historit upolitit [Study of the society and economy in Israel: Historical and political perspectives]. In A. Bareli, D. Gutwein, \& T. Friling Tuvia (Eds.), Chevra vecalcala belsrael: Mabat histori achshavi [Society and economy in Israel: Historical and contemporary perspectives] (pp. 1-5). Ben-Gurion Research Institute.

Bereitschaft, B., \& Scheller, D. (2020). How might the Covid-19 pandemic affect 21st century urban design, planning, and development? Urban Science, 4(4), Article 56.

Carpentieri, G., Guida, C., Fevola, O., \& Sgambati, S. (2020). The Covid-19 pandemic from the elderly perspective in urban areas: An evaluation of urban green areas in 10 European capitals. TeMA-Journal of Land Use, Mobility and Environment, 13(3), 389-408.

Cecik, M. (1968). Tichnun ubinuy arim [Town planning and construction]. Unpublished manuscript.

Cohen, E. (1970). The city in Zionist ideology. Institute of Urban and Regional Studies, Hebrew University.

Dekel, O. (2021). Ha'ish shelnu be-Wuhan [Our man in Wuhan]. Kinneret Zmora-Bitan Dvir.

Eisenstadt, S. N. (1989). Hachevra halsraelit betmuroteiha [The transformation of Israel society]. Magnes.

Freudendal-Pedersen, M., \& Kesselring, S. (2020). What is the urban without physical mobilities? Covid-19induced immobility in the mobile risk society. Mobilities, 16(1), 81-95. https://doi.org/10.1080/ 17450101.2020.1846436

Frisher, B. (Ed.). (2009). Hanchayot letichnun rechovot baarim-Merchav harechov [Guidelines for planning streets in cities-The street space]. Department of Transportation Planning, Ministry of Transportation and Road Safety; Department of the Chief Architect; Ministry of Construction and Housing.

Giedion, S. (1954). Walter Gropius: Work and teamwork. Architectural Press Print.

Golany, G. (1976). New town planning: Principles and practice. Wiley. 
Gugerell, K., \& Netsch, S. (2020). Reflection on the Austrian newspaper coverage of the role and relevance of urban open and green spaces in Vienna during the first Covid-19 lockdown in 2020. disP-The Planning Review, 56(4), 54-63.

Gupta, D., Biswas, D., \& Kabiraj, P. (2021). Covid-19 outbreak and urban dynamics: Regional variations in India. GeoJournal. https://doi.org/10.1007/s10708021-10394-6

Haney, D. H. (2007). Leberecht Migge's Green Manifesto: Envisioning a revolution of gardens. Landscape Journal, 26(2), 201-215.

Harlap, A. (Ed.). (1973). Israel bona 1973 [Israel builds 1973]. Department of Planning and Engineering, Ministry of Housing.

Harlap, A. (Ed.). (1977). Israel bona 1977 [Israel builds 1977]. Department of Planning and Engineering, Ministry of Housing.

Harlap, A. (Ed.). (1988). Israel bona 1988 [Israel builds 1988]. Department of Planning and Engineering, Ministry of Housing.

Howard, E. (1960). Garden cities of to-morrow: A peaceful path to real reform. MIT Press. (Original work published 1898)

Iranmanesh, A., \& Alpar Atun, R. (2021). Reading the changing dynamic of urban social distances during the Covid-19 pandemic via Twitter. European Societies, 23(sup1), 872-886.

Ito, N. C., \& Pongeluppe, L. S. (2020). The Covid-19 outbreak and the municipal administration responses: Resource munificence, social vulnerability, and the effectiveness of public actions. Revista de Administração Pública, 54(4), 782-838.

Jabareen, Y., \& Eizenberg, E. (2021). The failure of urban forms under the Covid-19 epidemic: Towards a more just urbanism. The Town Planning Review, 92(1), 57-63.

Jacobs, J. (1961). The death and life of great American cities. Random House.

Kaushal, J., \& Mahajan, P. (2021). Asia's largest urban slum-Dharavi: A global model for management of Covid-19. Cities, 111, Article 103097.

Knox, P. (2005). Vulgaria: The re-enchantment of suburbia. Opolis: An International Journal of Suburban and Metropolitan Studies, 2(1), 33-46.

Krier, L., \& Economakis, R. (1992). Leon Krier: Architecture \& urban design, 1967-1992. Academy Editions.

Krier, R. (1984). Urban space. Academy Editions.

Lak, A., Asl, S. S., \& Maher, A. (2020). Resilient urban form to pandemics: Lessons from Covid-19. Medical Journal of the Islamic Republic of Iran, 34, Article 71.

Le Corbusier. (1947). The city of to-morrow and its planning. The Architectural Press. (Original work published 1929)

Le Corbusier. (1967). The radiant city. The Orion Press. (Original work published 1933)

Lefebvre, H. (1968). Le droit à la ville [The right to the city]. Anthropos.
Lerman, E. (2008). Madrich letichnun, haktzaa uprisa shel sherutey mischar beshchunot megurim [Manual for planning, allocating, and deploying commercial services in residential neighborhoods]. Ministry of Construction and Housing.

Liu, L. (2020). Emerging study on the transmission of the novel coronavirus (Covid-19) from urban perspective: Evidence from China. Cities, 103, Article 102759.

Mendes, L. (2020). How can we quarantine without a home? Responses of activism and urban social movements in times of Covid-19 pandemic crisis in Lisbon. Tijdschrift voor economische en sociale geografie, 111(3), 318-332.

Merlin, P. (1971). New towns: Regional planning and development. Methuen.

Mertens, H., \& Golani, Y. (1973). Hashpaat hamivne hafizi shel shechunat hamegurim al eichuta hasvivatit [The influence of the physical structure of a residential quarter on its environmental quality]. In A. Harlap (Ed.), Israel bona 1973 [Israel builds 1973] (pp. 66-68). Ministry of Housing.

Ministry of Construction and Housing. (n.d.). Construction and housing. Gov.il. https://www.gov.il/ en/departments/ministry_of_construction_and_ housing

Ministry of Housing. (1964). Osef pirsumim [A collection of publications].

Paldi, A., Wolfson, M., \& Eldor, S. (1989). Chipusey derech babinuy hashchunati [Changing patterns in neighborhood design]. Ministry of Construction and Housing.

Parhi-Tzafrir Architects, \& Geoda. (2011). Hanchayot letichnun habait hameshutaf [Guidelines for condominium planning]. Department of Chief Architect, Ministry of Construction and Housing.

Perry, A. C. (1974). The neighborhood unit. In C. W. Richard (Ed.), Neighborhood and community planning: Comprising three monographs (pp. 21-140). Arno Press. (Original work published 1929)

Porphyrios, D. (1992). Introduction. In L. Krier \& R. Economakis (Eds.), Leon Krier: Architecture \& urban design, 1967-1992 (pp. 9-11). Academy Editions.

Ritter, P. (1964). Planning for man and motor. Pergamon Press.

Safdie, M. (1991). Modiin: Ir hadasha [Modi'in: A new town]. Ministry of Construction and Housing.

Schocken, H. (2000). Intimate anonymity-The Israeli pavilion in the 7th International Exhibition of Architecture in the Venice Biennial. Ministry of Foreign Affairs \& Ministry of Science, Culture and Sport.

Sepe, M. (2021). Covid-19 pandemic and public spaces: Improving quality and flexibility for healthier places. URBAN DESIGN International, 26, 159-173. https:// doi.org/10.1057/s41289-021-00153-x

Shadar, H. (2010). Evolution and critical regionalism. Journal of Urban Design, 15(2), 227-242.

Shadar, H. (2011). The linear city: Linearity without a city. The Journal of Architecture, 16(5), 727-764. https://doi.org/10.1080/13602365.2011.591591 
Shadar, H. (2013a). Mekhilatiyut meuletzet leindividualizm babinuy haironi hatziburi [From forced communality to individualism in public urban construction]. Iunim Bitkumat Israel, 23, 204-232.

Shadar, H. (2013b). The evolution of the inner courtyard in Israel: A reflection of the relationship between the Western modernist hegemony and the Mediterranean environment. The Journal of Israeli History, 32(1), 51-74.

Shadar, H. (2014). Avnei habinyan shel hashikun hatziburi: Shisha asorim shel bniya tziburit belsrael [The construction of the public housing: Six decades of urban construction initiated by the State of Israel]. Ministry of Construction and Housing.

Shadar, H., \& Oxman, R. (2003). Of village and city: Ideology in Israeli public planning. Journal of Urban Design, 8(3), 243-268.

Shapira, A., \& Han, I. (2008). Shtachim tziburiyim ptuchim baarim: Madrich tichnun [Open urban public spaces: Planning manual]. Ministry of Environmental Protection, Policy and Planning Cluster, \& Ministry of Construction and Housing.

Sharon, A. (1951). Tichnun physi belsrael [Physical planning in Israel]. Government Publishing House.

Sharon, A. (1976). Kibbutz + Bauhaus: An architect's way in a new land. Kramer.

Shinar, A. (1990). Maarach hatichnun haphisy [The array of the physical planning]. Ministry of Construction and Housing, Administration of Planning and Engineering.

Sitte, C. (1945). The art of building cities-City building according to its artistic fundamentals. Hyperion. (Original work published 1889)

Stein, C. S. (1949). Toward new towns for America: Radburn. The Town Planning Review, 20(3), 219-251.

Taut, B. (1919). Die Stadtkrone [The city crown]. Eugen Diederich.

Tel Aviv University. (2015). LCUD: Laboratory of Contemporary Urban Design. https://lcud.tau.ac.il

Tendais, I., \& Ribeiro, A. I. (2020). Urban green spaces and mental health during the lockdown caused by Covid-19. Finisterra: Revista Portuguesa de
Geografia, 55(115), 37-42.

The Hebrew University of Jerusalem. (n.d.). The Urban Clinic. https://en.urbanclinic.huji.ac.il

The Israeli Urbanism Forum. (n.d.). Israel Urban Forum. http://www.israelurbanforum.org.il

Trop, T., \& Sarig, G. (2012). Madrich letichnun gamin tziburiyim: Lefi sug yishuv, migzar uchlusia, ezor aklimi vetopographia [Manual for public garden planning: By settlement type, population sector, climate zone, and topography]. Ministry of Housing, Department of Chief Architect, Ministry of Environmental Protection, Ministry of Agriculture and Rural Development, Rotem Productions.

Ugolini, F., Massetti, L., Calaza-Martínez, P., Cariñanos, P., Dobbs, C., Ostoić, S. K., Marin, A. M., Pearlmutter, D., Saaroni, H., Šaulienè, I., Simoneti, M., Verlič, A., Vuletić, D., \& Sanesi, G. (2020). Effects of the COVID-19 pandemic on the use and perceptions of urban green space: An international exploratory study. Urban Forestry \& Urban Greening, 56, Article 126888.

Wasdani, K. P., \& Prasad, A. (2020). The impossibility of social distancing among the urban poor: The case of an Indian slum in the times of Covid-19. Local Environment, 25(5), 414-418.

Wiebenson, D., \& Garnier, T. (1969). Tony Garnier: The cité industrielle. Studio Vista Print.

Yoninah. (2011). Ben Yehuda Street pedestrian mall [Online image]. Wikimedia Commons. https:// commons.wikimedia.org/wiki/File:Ben_Yehuda_ Street_pedestrian_mall.jpg?fbclid=IwAR3LNGiit Q4QvihmIBnS9dWP3AJjCR-ICJDyDRW6CVF1usdlbfBalhHM

Zecca, C., Gaglione, F., Laing, R., \& Gargiulo, C. (2020). Pedestrian routes and accessibility to urban services: An urban rhythmic analysis on people's behaviour before and during the Covid-19. TeMA: Journal of Land Use, Mobility and Environment, 13(2).

Zhu, J., \& Xu, C. (2021). Sina microblog sentiment in Beijing city parks as measure of demand for urban green space during the Covid-19. Urban Forestry \& Urban Greening, 58, Article 126913

\section{About the Author}

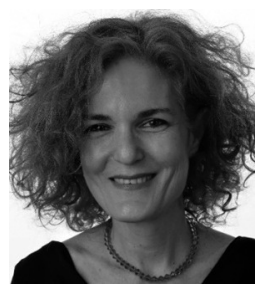

Hadas Shadar (PhD) is an architect and researcher of public housing and Brutalist architecture in Israel. She is a senior lecturer in the NB Haifa School of Design and in the Technion. Dr. Shadar is also a conservation adviser of master plans and a curator of exhibitions dealing with her areas of expertise. In 2013, she co-founded an association and website to promote the study of Israeli brutalism (https://www.brutalist-/architecture.org). 